Wyrok Sądu Metropolitalnego w Katowicach c. Sobański z 17 stycznia 1994 w sprawie o nieważność małżeństwa z tytułu niezdolności do podjęcia istotnych obowiązków małżeńskich (kan. 1095, n. 3)

Ius Matrimoniale 1 (67), 221-242

1996

Artykuł został zdigitalizowany i opracowany do udostępnienia w internecie przez Muzeum Historii Polski w ramach prac podejmowanych na rzecz zapewnienia otwartego, powszechnego i trwałego dostępu do polskiego dorobku naukowego i kulturalnego. Artykuł jest umieszczony w kolekcji cyfrowej bazhum.muzhp.pl, gromadzącej zawartość polskich czasopism humanistycznych i społecznych.

Tekst jest udostępniony do wykorzystania w ramach dozwolonego użytku. 


\section{Wyrok Sądu Metropolitalnego w Katowicach c. Sobański z 17 stycznia 1994 w sprawie o nieważność małżeństwa z tytułu niezdolności do podjęcia istotnych obowiązków małżeńskich (kan. 1095, n. 3)}

\section{Przebieg sprawy}

AG, (...) oraz GD, (...) zawarli małżeństwo 20.10.1990 w kościele (..) w $\mathrm{K}$. Ważność tego małżeństwa zaskarżył AG pismem, jakie wpłynęło do Sąu (wtedy) Biskupiego w Katowicach 9.9.1991. Sąd Biskupi przyjął sprawę do procesu 5.2.1992, a biorąc pod uwagę replikę pozwanej ustalił jego przedmiot $\mathrm{W}$ formie pytania: czy udowodniono nieważność małżeństwa stron $\mathrm{z}$ tytułu niezdolności do podjęcia $\mathrm{i}$ wypełnienia istotnych obowiązków małżeńskich z przyczyn natury psychicznej po stronie powoda jak i pozwanej. Dekretem z 14.7.1992 zamknięto postępowanie dowodowe, ale na sesji $w$ dniu 1.3.1993 sędziowie stwierdzili, iż instrukcję sprawy należy uzupełnić. Po uzupełnieniu materiału dowodowego zamknięto postępowanie 13.12.1993. W dniu 7.1.1994 Sąd Metropolitalny wydał następujący wyrok:

\section{Motywy prawne}

Wgląd w narosłe akta sprawy każe prawną motywację wyroku zacząc od zarysowania, o co chodzi $w$ kanonicznym procesie o orzeczenie nieważności małżenstwa. To zaś wymaga przypomnienia podstawowych założeń kościelnego prawa małżeńskiego.

Według nauki Kościoła małżeństwo to „przymierze, przez które mężczyzna i kobieta tworzq ze sobq wspólnotę calego życia, skierowanq ze swej natury do dobra matzonków oraz do zrodzenia $i$ wychowania potomstwa" (kan. 1055 § 1). Źródło takiego charakteru małżeństwa Kościół widzi w stwórczej woli Boga. Małżeństwo między ochrzczonymi jest 
rzeczywistością nie tylko ziemską, lecz nadprzyrodzoną, zostało „podniesione przez Chrystusa Pana do godności sakramentu” (kan. 1055 $\S 1)$. Jego istotne przymioty to "jedność $i$ nierozerwalność, które $w$ malżeństwie chrześcijańskim nabieraja szczególnej mocy $z$ racji sakramentu" (kan. 1056). Małżeństwo powstaje przez wyrażoną zgodnie $z$ prawem zgodę stron prawnie do tego zdolnych, której to zgody "nie może uzupetnić żadna ludzka władza" (kan. 1057 § 1), a która jest ,aktem woli, którym mężczyzna $i$ kobieta $w$ nieodwołalnym przymierzu wzajemnie sie sobie oddaja i przyjmujq w celu stworzenia malzeństwa" (kan. 1057 §). Fakt, że małżeństwo powstaje przez akt woli, to jeden $z$ wyznaczników kanonicznego prawa małżeńskiego. Istotny jest bowiem wewnętrzny akt woli, a nie tylko jej oświadczenie. Jeśli nie ma takiej woli, czy to dlatego, że mimo zewnętrznego oświadczenia nie towarzyszy jej odpowiadajacy jej zamiar, czy to dlatego, że dotykają ją jakieś braki, nie może zaistnieć małżeństwo. Dlatego przedmiotem procesu o nieważność małżeństwa jest właśnie istnienie $\mathrm{i}$ stan woli nupturientów w chwili jej wyrażenia czyli w momencie zawierania małżenstwa. Kościół nie może rozwiązać małżeństwa faktycznie czyli ważnie zawartego (i dopełnionego), może natomiast - a jeśli przynajmniej jedna ze stron zwróci się o to, musi - badać, czy małżeństwo zostało ważnie zawarte, w tym przypadku: czy zewnętrznemu oświadczeniu towarzyszył prawdziwy, nie dotknięty brakiem akt woli.

Sens dyspozycji prawa kanonicznego dotyczacych braków woli można zrozumieć jedynie, jeśli ma się równocześnie na oku dwie determinujące je zasady. Pierwsza $\mathrm{z}$ nich to wspomniana dopiero co zasada, że małżeństwo powstaje przez akt woli. Druga $\mathrm{z}$ nich to naturalne prawo każdego człowieka do zawarcia małżeństwa. Zasad tych nie wolno rozpatrywać $w$ izolacji. Przyjęcie pierwszej z nich w oderwaniu od drugiej prowadziłoby do wniosku, że w każdym przypadku konieczna jest świadoma, pozytywna aprobata wszystkich poszczególnych elementów małżeństwa. Oznaczałoby to, że nawet najmniejszy brak woli powodowałby jej prawną nieskuteczność. Skutkiem byłyby zbyt wysokie wymagania stawiane nupturientom, co w efekcie godziłoby w prawo każdego - także "prostego" - człowieka do zawarcia małżeństwa. Stąd konieczność uwzględnienia także drugiej ze wspomnianych zasad, właśnie prawa osoby do zawarcia malżeństwa. Z kolei izolacyjne przyjęcie tej zasady mogłoby - wobec nierozerwalności małżeńskiej - prowadzić do konsekwencji nieludzkich, przez skazywanie na życie w małżeństwie wymuszonym, wyłudzonym lub 
$\mathrm{z}$ osobą do niego niezdatną. Tak pojęte prawo jednej osoby uderzałoby wtedy w prawa drugiej.

Zadaniem prawodawstwa kościelnego jest wyciagnięcie praktycznych wniosków harmonizujących obydwie zasady i ustalenie norm, które równocześnie chroniłyby prawa człowieka i świętość małżeństwa. Prawodawca kościelny, stojąc na niewzruszonym gruncie obydwu zasad, opiera się na wiekowym doświadczeniu Kościoła i stara się uwzględnić sprawdzone osiagnięcia wiedzy, w tym przypadku wiedzy o fizycznej i psychicznej strukturze osoby ludzkiej. Dyspozycje prawne ulegają ewolucji odpowiednio do doświadczenia i wiedzy, zawsze jednak trwają niezmiennie przy niekwestionowalnym założeniu nierozerwalności ważnie zawartego (i dopełnionego) małżeństwa. Znaczy to, że przedmiotem procesu o nieważność małżeństwa nie sa wydarzenia poślubne ani też faktyczne wywiazzywanie się małżonków z przyjętych zobowiązań, lecz akt woli konstytuujący małżeństwo. Pytanie brzmi: czy zachodził brak woli - i to nie „jakiś" brak, lecz taki, który wedle rozumienia Kościoła utrwalonego w normach prawa kanonicznego powoduje nieważność małżeństwa od samego jego początku.

W literaturze (np. K. Lüdicke, MK, Einf. 1095) rozróżnia się pierwotne, bezpośrednie oraz wtórne, pośrednie braki woli. Pierwotne mają miejsce wtedy, gdy oświadczenie woli mija się z faktyczną wolą (symulacja, uwarunkowanie małżeństwa). Wtóme zachodza, gdy nupturient nie uświadamia sobie prawnych braków swej woli (defekt rozeznania, błąd, przymus nie rodzacy symulacji). Do tych ostatnich trzeba też - w aktualnej systematyce kanonicznego prawa małżeńskiego - zaliczyć brak określony kan. 1095 n. 3, na którego podstawie prowadzi się niniejszą sprawę.

Kan. 1095 n. 3 brzmi: , Niezdolni do zawarcia matżeństwa sq ci, którzy z przyczyn natury psychicznej nie sq zdolni podjać istotnych obowiqzków matżeńskich". Dyspozycja ta bazuje na założeniu, że nikt nie może prawnie zobowiązać się do tego, czego nie potrafi wykonać. Jest to elementarna zasada prawa natury, akcentowana już $w$ starożytnych i średniowiecznych źródłach prawa (Reg. 6 in $\mathrm{VI}^{\circ}$ ). Kan. 1095 n. 3 konstatuje niezdolność z przyczyn natury psychicznej. Przyczyn tych nie należy utożsamiać $z$ chorobą psychiczna, aczkolwiek choroby takie mogą się wśród nich mieścić. Niezdolność do podjęcia istotnych obowiązków nie przekreśla zdolności do rozeznania ani w ogóle „,zdolności życiowych” danej osoby. 
Aplikacja kan. 1095 n. 3 wymaga przeto ustalenia, co należy rozumieć przez ", istotne obowiqzki matżeńskie" oraz jakie przyczyny uniezdalniaja do ich podjęcia.

Analiza tego, co składa się na istotne obowiązki małżeńskie, musi wyjść od cytowanego wyżej ujęcia istoty małżeństwa w kan. $1055 \S 1$. Wspólnota małżeńska to wedle nauki Soboru Watykańskiego II ,głęboka wspólnota życia i mitości" (GS 48), obejmujaca aspekty nie tylko fizyczne, lecz także duchowe. Zaistnienie takiej wspólnoty zakłada zdolność do wzajemnego oddania się i przyjęcia. Dzięki temu powstaje międzyosobowa jedność, w której wzajemna miłość małżonków odpowiednio się wyraża, rozwija i dojrzewa (por. GS 50). Chodzi - naucza Pawel VI - „o mitość petna, to znaczy o tę szczególnq forme przyjaźni, poprzez która malżonkowie wielkodusznie dziela między sobq wszystko, bez niesprawiedliwych wyjatków i egoistycznych rachub" (enc. Humanae vitae 9). Kłóci się z taką miłością egoizm, szukanie siebie, tendencje do panowania i rządzenia, samolubstwo, brak tolerancji. W świetle orzecznictwa kościelnego małżeństwo wymaga zdolności do oddania się drugiej osobie zarówno w sferze fizycznej jak i duchowej przy zachowaniu autonomii i godności osób; zdolności do przezwyciężania własnego egoizmu oraz do dostrzegania własnych niedostatków; zdolności do akceptacji drugiego człowieka oraz do zrozumienia jego cech i gustów własnych; zdolności do szanowania zdania odrębnego i do ustępstw w sytuacjach konfliktowych, mówiąc krótko: zdolności do wyjścia poza swój własny świat. Podkreślić przy tym trzeba wyłączność wspólnoty małżeńskiej. Tworzy ona jedność uwarunkowaną miłością. Zawierający małżeństwo muszą być zdolni do nawiązania takiej wspólnoty, nie dzielonej między osoby trzecie, spoza malżeństwa. "Dlatego opuści czlowiek ojca $i$ matkę swojq $i$ zlaczy się $z$ żonq swojq $i$ będq dwoje w jednym ciele" (Ef 5,32) - co oznacza oddanie się bez reszty $\mathrm{i}$ ofiarne współdziałanie dla wzajemnego dobra. Tego wszystkiego małżonkowie mają prawo wzajemnie oczekiwać, to wszystko składa się na małżeństwo i tym samym należy do jego kształtu prawnego.

Oczywiste jest, że oczekiwania ludzkie nigdy nie zostają na ziemi w pełni spełnione, dotyczy to również oczekiwań wiązanych z małżeństwem. Zawarcie małżeństwa to zawsze ryzyko niepewnej przyszłości, a każdy nupturient wie, że on i druga strona podlegają słabościom ludzkim. Stąd w procesie o nieważność małżeństwa nie chodzi o to, czy małżonkowié faktycznie wykonywali swe obowiazki małżeńskie, ani też o to, czy i jak 
stawiali czoło trudnościom życiowym. Realizacja obowiązków małżeńskich, pokonywanie $w$ miarę sił i możliwości nastręczających się trudności to obowiązek etyczny. Spełnianie tych obowiązków to sprawa sumienia małżonków i nie podlega ono ocenie Sądu, który skupia się wyłącznie na zagadnieniach prawnych, to znaczy na przekazaniu i przyjęciu praw małżeńskich, gdyż na tym polega $-\mathrm{z}$ punktu widzenia prawa zawarcie małżeństwa. W rozpatrywanej sprawie nie chodzi o wolę przekazania praw konstytuujących wspólnotę małżeńska, lecz o zdolność do takiego aktu. Jeśli takiej zdolności brak, zobowiązanie małżeńskie nawet przy najlepszej woli pozostaje czcze.

Jeśli więc małżeństwo okazało się ,nieudane" (takie zostaje zaskarżone w Sądzie kościelnym), Sąd musi uzyskać odpowiedź na pytanie, czy "nieudanie" wynikło z niepokonalnych trudności poślubnych, z braku woli ich pokonania, czy też nastapiło dlatego, że małżeństwo z danym partnerem przerastało moźliwości psychiczne osoby je zawierającej (ARRT Dec. 79,1992,12). Nie chodzi przy tym o zdolność do sprostania wymogom wygórowanym, wyidealizowanym, lecz takim, które wedle nauki i praktyki chrześcijańskiej należą integralnie do małżeństwa, a której to zdolności brak uniemożliwia prowadzenie życia małżeńskiego. Niemożliwość ta praktycznie ujawnia się po ślubie, lecz powodujące ją przyczyny musza istnieć już w momencie zawarcia małżeństwa, gdyż stan wtedy istniejacy decyduje o ważności związu.

Aby Sąd mógł orzec nieważność małżeństwa, musi osiagnąć moralną pewność o istnieniu określonych prawem - w tym przypadku kan. $1095 \mathrm{n}$. 3 - podstaw nieważności. Pewność tę może czerpać wyłącznie z akt sprawy, tj. z zawartych w aktach faktów i dowodów (kan. 1608 § 2). Fakty, o których mowa, to wszelkie zaszłości utrwalone w aktach sprawy, a związane $z$ procesem i jego przedmiotem, wśród nich także stawiane wnioski i zarzuty. Dowody to oświadczenia stron, zeznania świadków, dokumenty i opinie biegłych. Dopuszczenie i ocena dowodów należy do sędziego. Świadków przedstawiają strony (sędzia ma prawo ograniczyć zbyt wielką liczbę świadków - kan. 1553), biegłych powołuje Sąd. Od biegłych $w$ sprawach o nieważność małżeństwa wymaga się nie tylko wiedzy specjalistycznej, lecz także znajomości i akceptacji nauki Kościoła o małżeństwie. Ocena ich opinii należy do Sądu, który weryfikuje przesłanki opinii i rozważa wnioski w całokształcie materiału dowodowego (kan. $1579 \S 1$ ) 
Pewność moralna (kan. 1608 \& 1) to nie pewność uzyskiwalna w matematyce czy naukach przyrodniczych, lecz pewność zdobyta droga wnioskowania logicznego i oceniającego. Pozytywnie charakteryzuje się ona tym, że wyklucza rozsądne i uzasadnione wątpliwości, negatywnie zaś tym, że nie wyklucza absolutnie innych możliwości (Pius XII, przem. z 1.10.1942 - AAS 1942, 339). Wyrok w sprawach małżeńskich ma charakter deklaratywny, u jego podstaw stoi nie wola Sądu, lecz poznanie. Przed oceną subiektywną chronią sędziów ustalone prawem reguły dowodzenia, których przestrzeganie obiektywizuje pewność moralną. Pewność taką muszą osiągnąc orzekający w sprawie sędziowie, w sądzie kolegialnym - a taki rozpatruje sprawy małżeńskie - dochodzi się do niej według reguł ustalających podejmowanie decyzji kolegialnych (kan. 1426 $\S 1)$.

Przedmiotem procesu - i konsekwentnie wyroku - jest tylko i wylącznie kwestia nieważności małżeństwa. Dlatego proces taki nie jest z natury swej procesem spornym, acz prowadzi się go wedle procedury procesu spornego. Osoba wnosząca skargę o orzeczenie nieważności małżeństwa nie wnosi roszczeń wobec drugiej strony, lecz domaga się od Kościoła - konkretnie: od Sądu kościelnego - orzeczenia nieważności małżeństwa. Jeśli Sąd osiąga moralną pewność co do tej nieważności, musi ją orzec niezależnie od stanowiska drugiej strony. Ze względu na figurę procesu spornego nazywa się wnoszącego sprawę powodem, drugą stronę nazywa się pozwaną. Stroną prawdziwie pozwaną jest jednak władza kościelna, od której powód domaga się orzeczenia nieważności małżeństwa i wyciągnięcia $\mathrm{z}$ tego orzeczenia wniosków co do stanu osób ( $\mathrm{Z}$. Grocholewski, Periodica 1990, 357-391). Niesporny charakter procesu rysuje się wyraźnie wtedy, gdy obydwie strony zgodnie proszą o orzeczenie nieważności - mimo to mówi się wtedy o stronach jako o powodzie i pozwanym. Strony mogą się oczywiście różnić w ich poglądach na ważność małżeństwa względnie co do podstaw nieważności, Sąd jednak nie może kierować się ich poglądami za czy przeciw, lecz jedynie obiektywną prawdą wyłaniającą się z akt sprawy. Sąd musi swój wyrok uzasadnić argumentami prawnymi i faktycznymi. Wyrok orzekający nieważność małżeństwa, także z powodu niezdolności osoby prawnie niezdolnej do zawarcia małżeństwa, nie ma charakteru dyskryminującego - Sąd nie wypowiada się wtedy o winie, lecz o nieistnieniu węzła małżeńskiego. W szczególności orzeczenie nieważności małżeństwa na podstawie kan. 1095 
n. 3 w żaden sposób nie dotyka problemu winy, opiera się bowiem na istotnym dla aplikacji tego kanonu założeniu ",chcial, ale nie mógt". Dotyczy to zawsze konkretnego, rozpatrywanego i orzekanego przez Sąd małżeństwa, nie ma charakteru generalnego.

\section{Stan faktyczny}

„, Nierozerwalny, bardzo silny zwiqzek mojej żony z jej matkq, któremu wszystko jest podporzqdkowane, nic poza nim nie jest ważne, a który mnie ujawnit się dopiero po ślubie, niedojrzatość emocjonalna żony, zupelny brak zrozumienia przez nia istoty matżeństwa, brak poczucia jedności, wspólnoty z mężem, nawet brak minimum szacunku i zrozumienia drugiego czlowieka, traktowanie męża instrumentalnie, dzięki któremu może mieć dziecko i który jest shuga spetniajacym życzenia żony, która z siebie nie daje nic, widzenie mężzyzny, męża jako uosobienie zla, brak poczucia przez żonę obowiazków, jakie naklada na malżonków matzeństwo" (k . 2) - to według skargi powoda podstawy faktyczne nieważności małżeństwa stron, uzasadniające prowadzenie sprawy z kan. $1095 \mathrm{n}$. 3. Wywody powoda to jakby komentarz do tego kanonu. Następnie na dwunastu stronach opisuje dzieje swego małżeństwa kończąc konkluzja, że przyczyny takiego postępowania , muszq leżeć w jakiejś nienormalności" (k. 15).

Pozwana replikuje, że przytoczony wyżej tekst to "tyle wymyślnych $i$ wyimaginowanych zarzutow, że trudno byłoby znaleźć ich więcej", i zarzuca powodowi „powszechne postugiwanie się ktamstwem” (k. 22). Pozwana w replice ogranicza się do „części najważniejszych zarzutów”, gdyż gdyby chciała „odpowiedzieć na wszystkie, powstalaby ksiqżka” (k. 22). Mimo to replika zajmuje czternaście stron i stanowi po prostu odwrócenie zarzutów powoda.

Podobnie ukierunkowane są zeznania stron. Powód twierdzi, że żenił się z miłości i był przekonany, że pozwana go kocha. Oboje chcieli ślubu kościelnego, nieporozumień przed ślubem nie było, ,dopiero ostatnie dwa tygodnie przed ślubem pozwana byla zdenerwowana, przejęta wszystkimi szczególami" (k. 62,3). Problemy, jakie stwarzala w związku ze ślubem, tłumaczył sobie tym, że ona , chce, by wszystko na ślubie wypadto jak najlepiej” (k. 62,4). Był przekonany, że „pozwana potrafi prowadzić dom", nie zauważył, , by była nadpobudliwa czy nerwowa”, ani ,, by była 
osobq konfliktowq". Do matki "odnosila się przed ślubem życzliwie, natomiast wobec ojca obojętnie", nie zauważył jednak "przed ślubem nadmiernego zwiqzku pozwanej $z$ matkq", która nie uczestniczyła w spotkaniach przedślubnych stron (k. 62,4). W dniu ślubu był „zmęczony realizacja wymagań pozwanej" (k. 63,5). O życiu poślubnym zeznaje: „Po ślubie zamieszkaliśmy $w$ naszym mieszkaniu. Pierwsza poważniejsza sprawa była 2 tygodnie po ślubie. Poszło o to, że ja chciatem jechać do domu, urzadzać dalej mieszkanie, a pozwana chciata jeszcze zostać u mamy. Zaproponowatem pozwanej, żeby została u mamy, a ona wtedy powiedziała, ze mam się wynosić, że ja się chyba z niq ożenilem dla majatku. Pozwana byla tam od rana, ja przyjechatem po niq po pracy. Staratem się udobruchać pozwanq. Pojechaliśmy razem do domu. Takie spięcia powtarzaly się jednak, chodzito o drobiazgi. Zaczęto się okazywać, że dla pozwanej najdrobniejsza rzecz jest problemem, np. kiedy kupiliśmy wykladzine do kuchni i po jej przyklejeniu przestała się podobać pozwanej, pozwana zaczęla plakać. Pozwana zrobiła mi też awanturę, że wśród zdjęć ślubnych, jakie robił mój brat, nie bylo ujęcia, jak ona przyjmuje Komunię. Pozwana wręcz oskarzyla brata, ze zrobit to celowo. Tak samo nie bylo zdjęcia, jak jej matka sklada jej życzenia. Byl jednak film video. Mówilem pozwanej, że to sq drobiazgi. Juz 6 stycznia pozwana chciala odejść po kolejnej kłótni o te zdjęcia. Zatrzymatem ja wtedy. Musialem jednak podrzé te ujęcia, jakich ona nie miala. Pozwana jednak odeszla 22 stycznia. Pozwana odeszła, gdy bytem w pracy, zostawita tylko kartke, jaka zalqczylem do skargi” (k. 63,6). Kartka ta jest następującej treści: „Żegnaj! Wiedzialam, że biore cię z krzywym interesem - ale nie wiedzialam, że nie chcesz mieć dzieci i że Twoja żona powinna być mama. Po resztę rzeczy wrócę, ale nie sama - nie zostawię tego domu tak jak wyglada - bo w 90\% to moja zastuga. G." (k. 20). Po dziesięciu dniach strony spotkały i pogodziły się, ,w polowie lutego pozwana znów odeszla na 2-3 tygodnie", ostatecznie odeszła 16 kwietnia. Przedtem pytała powoda, czy będzie gotował jej obiady, zarzucała, że jeździ zbyt często do swoich rodziców i że nie potrafi „zrobić jej dziecka”. Zaszła jednak w ciążę, wedle powoda „problemów z samym wspólżyciem nie byto" (k. 63,6). O związu pozwanej $\mathrm{z}$ matka tak zeznaje: „Ja uważam, że pozwana jest niesamodzielna i przywiqzana do matki. Pozwana chciata, żeby matka zamieszkała z nami. Twierdzi, że się mnie boi. Mówiła, że jak jej matka umrze, to ona umrze 3 dni po niej. Mówiła, że jej matka jest najlepsza na 
świecie. Poza tym, kiedy się spotykaty, ściskaty się, całowaty, pieścity. Pierwszy raz to zauważylem w Boze Narodzenie. Po urodzinach pozwanej przez godzinę ściskaly się $w$ naszej sypialni. Dla mnie było to szokujace. W trakcie spotkania u księży powiedzialem pozwanej, że musi wybrać między mnq a matkq. Pozwana powiedziala, że wybiera matkę. W maju jeszcze raz pozwana oświadczyla, że zostanie, ale będzie spala na jednym tapczanie $z$ matka. Ja się na to nie zgodzitem" (k. 63-64,7). Wedle powoda pozwana wszelkie decyzje podejmowała po konsultacji z matka, ,bez mamy nie potrafita się znaleźć" (k. 34,7). Powód zdaje sobie sprawę, że pozwana oskarża go i jego rodzinę dokładnie o to samo, co on zarzuca pozwanej.

Pozwana naświetla po swojemu konflikty opisane przez powoda. Zeznaje, że kochała powoda, wydawało się jej, że i on ją kocha. Chciała $z$ nim wprawdzie zerwać, bo wydawało się jej, że ,coś jest nie tak", ale nie doszło do zerwania, bo powód stwierdzit, że nie wyobraża sobie życia bez niej. Jej matka była przeciwna małżeństwu, gdyż „zwróciła uwage, że powód jest nerwowy, stale skubat twarz, klepat sie po kolanach" (k. 66,3). Pozwana miała wcześniej innych chłopaków, ale ,najbardziej poważnie traktowata powoda" (k. 66,4). Twierdzi, że „wszystko byto idealnie”, równocześnie podaje, że nie podobało jej się to, iż powód rozmawiając nie patrzał na nią i skubał twarz, ponadto po pierwszej nauce przedślubnej przyznał się, że „ma skrzywienie prqcia”. Od jego matki dowiedziała się, że ",powód jest takim dużym dzieckiem", że on ", nie poradzi sobie w życiu”, ale "nadmiernego zwiazku powoda z matkq" nie zauważyła (k. 66,4). Natomiast po ślubie „powód wszystko ustalal ze swoimi rodzicami” i nawet wtedy, gdy strony uzgodniły coś wspólnie, ,powód po powrocie do rodziców mówit, że będzie inaczej". Pozwana zaprzecza poszczególnym zarzutom powoda i stwierdza: ,To, co powód pisze, to sq klamstwa $i$ oszczerstwa” (k. 67,6). O rozejściu stron pozwana tak zeznaje: „Pierwszy raz odeszłam w styczniu, kiedy powód odmówil mi w dni plodne wspólżycia. $W$ tym samym dniu wrócilam z moimi rodzicami, którzy chcieli porozmawiać $z$ rodzicami powoda. Rodzice nie pokazali się, natomiast powód wrócit o 22.00 i powiedziat mi, że mam się wynosić, że to jest jego mieszkanie. Styszata to moja rodzina. Powód pobiegt na balkon i zacząl wolać: ratunku. Później okazało się, że jego ojciec czekat pod balkonem, ponieważ za chwile zjawil się $z$ milicja. Następnego dnia pojechatam $z$ mamq do teściów, żeby pewne sprawy wyjaśnić. Teściowie krzyczeli, że nas zniszcza, że przyjechalyśmy prosić o milość. Po 10 dniach jednak wróciłam 
do domu. Po tych wydarzeniach zachorowalam na nerwice serca. Wcześniej jeszcze bylam u psychologa rejonowego dra M., ponieważ wydawato mi się, że powód nie zachowuje się normalnie. Lekarz powiedziat mi, że przed godzina byl u niego powód. Skarżyl się na mnie. Drugi raz bylam zmuszona odejśc w lutym, bo, jak zeznalam, zachorowatam na nerwice serca. Źle sie wtedy czulam, prositam powoda, zeby zostal ze mnq, nie wyjezdzat na narty. Powód stwierdzil, że sobie życia przeze mnie nie bedzie marnowat i pojechat. W kwietniu okazato sie, ze jestem w ciazy. Czutam siéże, wiec pojechalam do rodziców, by troche odpoczać. Pragne dodać, że kiedy powiedziatam powodowi, że jestem prawdopodobnie w ciaży, w ogóle nie zareagowat. Do rodziców pojechatam po poludniu 16 kwietnia, a 17 rano miatam już telefon powoda, ze wymienit zamek, ze jak będe chciata wrócić, to mam zadzwonic. Zadzwonitam po dwóch dniach, ale powód tylko rzucit stuchawkq" (k. 67,6). Pozwana pragnęła się pogodzić, także za pośrednictwem Ojców Franciszkanów i Diecezjalnej Poradni Życia Rodzinnego, chciała jednak odrębnego mieszkania, gdyż powód robil, co chcieli jego rodzice, a ją traktowano jak służąca, bez praw (k. 68,7).

Powód przedstawił 23 (!) świadków, w tym rodziców pozwanej i dwóch jej braci, pozwana piętnastu, spośród których dziesięciu figurowało już na liście powoda. Ta więc strony zaproponowały łącznie 28 świadków. Sąd dekretem z 24.3.1992 dopuścił ośmiu, po trzech z kazdej rodziny, pania KW wysuniętą przez obydwie strony oraz p. EJ podanego przez powoda. $\mathrm{O}$ tym ostatnim pozwana $\mathrm{z}$ góry zaznaczyła, że ,nie może nic powiedzieć o naszym życiu matżenskim, gdyż podczas naszego wspólnego zamieszkiwania nie byl w naszym mieszkaniu ani razu, jak równiez myśmy nie byli u niego, ani tez nie kontaktowaliśmy sie", ponadto pozwana wie o nim z „opowiadań męza, że jest on posluszny teściom" (k. 56). Ograniczenie liczby świadków musiało nastạpić, gdyż sprawa od poczatku przybrała charakter konfliktowy, zaś oświadczenia pisemne świadków przedłożone przez pozwaną (k. 41-43) dotyczące spraw słabo związanych z przedmiotem procesu dowodziły, iż strony prezentując świadków straciły z oczu przedmiot procesu.

Ojcu powoda, JG, wydawało się, że malżeństwo stron będzie udane, i w takim też przekonaniu trwała rodzina powoda przez dwa miesiące po ślubie stron. O konfliktach świadek zeznaje: "Syn miat już przed ślubem mieszkanie, jakie mu kupiłem. Tam strony zamieszkały po ślubie, Byli razem 
3 miesiace. Nieporozumienia zaczety się prawdopodobnie po 2 tygodniach, tylko syn to ukrywat. Chodzito o różne drobiazgi, np. o zdjęcia. Nieporozumienia prowokowata pozwana. Myśmy byli przekonani, że wszystko między stronami jest dobrze, bo wiedzieliśmy, jakiego mamy syna. Strony czasami wpadaly do nas i niczym nie podpadaty. Dopiero 1 stycznia zadzwonila matka pozwanej i powiedziala nam, że strony źle żyja. Zaczęla też mówić, że syn nie nadaje się do malżeństwa, że nie opiekuje sie pozwanq, że pozwana źle wyglada. Pragnę dodać, że syn pracowat, zaś pozwana od sierpnia juz nie pracowala. Na mój wniosek obie rodziny spotkaly się 6 stycznia w mieszkaniu stron na urodzinach pozwanej. Pozwana od drzwi nas zaatakowata. Matka pozwanej milczata. Dowiedzieliśmy się, że rodzice już wcześniej zrobili synowi awanturę, że nie opiekuje sie pozwana. Pozwana grozila, że odejdzie. Kiedy syn pytat ja, co zawinit, nie powiedziala ani slowa. Do syna mieli pretensje, że jest malomówny. Tam nie bylo żadnych przyczyn poważnych, tylko coś się wmawialo. Spotkanie skończylo się pojednaniem. Syn nic nie zarzucat pozwanej, on nie umiat wydusić z siebie slowa. Dnia 22 stycznia po powrocie z pracy syn zastat kartke, że pozwana odchodzi. Syn bardzo źle sie poczul, bolata go glowa. Po jakims czasie zadzwonil do nas ojciec pozwanej, że wychowaliśmy sadyste, narkomana. Nic jednak więcej nie mówit, groził tylko synowi $i$ nam. Pojechalismy z synem do mieszkania stron $z$ tym, że ja zostatem na dole. Ojciec $i$ brat pozwanej przyjechali tam $i$ pobili syna. Ja pojechatem po pomoc na policję. Później jeszcze pozwana pare razy przychodzila do syna i odchodzita. Syn chcial się dogadać $z$ pozwanq. Po tym pobiciu syn sobie zastrzegt, żeby tam nie przychodzily rodziny, a oni stale tam bywali, ustawiali syna. Pozwana nie umiata sie obejść bez matki, kiedy syn szedl do pracy, to siedziata u niej" (k. 73-74,7).

Podobne $\mathrm{w}$ treści sa zeznania matki powoda XG: „Po ślubie strony mieszkaty $w$ mieszkaniu syna. Do końca roku wydawato nam sie, że wszystko między nimi jest dobrze. Czasami bywaliśmy u stron. Spotykaliśmy tam matke pozwanej $i$ jej brata. Matka szyła zastony. W listopadzie podpadto mi, że syn jest jakiś blady i smutny. Thumaczyt się urzqdzaniem mieszkania, przemęczeniem. Dnia l stycznia zadzwonila do nas matka pozwanej. Zapytala, czy wiem, co dzieje się z naszymi dziećmi. Później powiedziata, że syn nie nadaje się do matżeństwa, że nie pomaga, jest nieopiekuńczy, że pozwana przy nim choruje. Ja zaprzeczylam temu, bo to bylo nieprawda. Syn następnego dnia powiedziat mi, że nie wolno mu 
przychodzić do nas. Powiedzial mi, ze pozwana ma pretensje o wszystko, o zdjecia, o taniec. Powiedziat mi, że pozwana nic nie robi $w$ domu, np. jak ugotuje zupe, to robi wielka laske. Poza tym nie daje się przekonać, jest jak beton. Spotkaliśmy sie wszyscy na urodzinach pozwanej, zeby porozmawiać. Pragne dodać jeszcze, że syn mówit mi, że pozwana wpada w euforie na widok swojej matki, choć widzi ja codziennie. Wobec niego zaś zachowuje sie obojętnie. Syn pytal mnie, jak ma z tego wyjść. Na urodzinach pozwanej pozwana przywitata nas krzykami. Nie wiem, co krzyczata, bo zaczęlam sie trzaśś, nie wiedziatam, co sie dzieje. Matka pozwanej nic nie mówila. Natomiast ojciec zaczał mówić, że katolicy, że nie chea dzieci. Mowil to do nas, tak jakbysmy to my decydowali o dzieciach. Wiem, ze syn chcial dzieci. Nie wiem, dlaczego stawiano mu taki zarzut. Próbowatam godzić strony. Syn chciat pocalować pozwanq ale ona go odepchnęla. Strony dalej zyly ze soba. Pozwana odeszla 22 stycznia. Syn przyszedt do nas zrozpaczony z kartka pozwanej. Bardzo to przezywat. Ojciec pozwanej zadzwonit wtedy z pogrózkami. Mówil, ze wychowatam sadystę, że mnie zniszczy. Syn pojechat do siebie. Tam pobili go ojciec pozwanej $i$ jej brat. Później strony jednak jeszcze sie spotykaly, sypiali razem. Pod koniec marca pozwana zaszla w ciaże. Strony nie mieszkaly razem, bo syn nie godzil sie, by razem z nimi mieszkata matka pozwanej. Kiedy urodzilo sie dziecko, syn napisal do pozwanej list, ale ona mu nie odpisata. Nie wpuścila go tez" (k. 75,7).

Brat powoda, RG, wie o nieporozumieniach, ale nie jest co do nich zorientowany: "Nie wiem, o co chodzilo stronom w czasie awantur, tzn. co sobie zarzucali. Pozwana nie potrafila przedstawić żadnych zarzutów bratu. Jednocześnie nie widziala zadnej winy $w$ sobie, kiedy jq o to pytatem" (k. 76,7).

EJ, sąsiad rodziców powoda, poznał pozwaną krótko przed ślubem stron. Zeznaje: „Wiem, ze powód byt bardzo zakochany, nic nie widziat poza pozwanq. Matka powoda prosita mnie, żebym np. nic nie przygadal pozwanej, gdybym sie z niq spotkat, zeby przez to nie skrzywdzic powoda. Oni byli przeświadczeni, że jak powód sobie kogoś znajdzie, to bedzie to osoba super. Wiem, ze pozwana podobata się matce powoda, że jest ona religijna $i$ gospodarna, tak sie wyrażala o niej wobec nas. Powód jest czlowiekiem bardzo zrównoważonym. Ja raz spotkatem pozwana przed ślubem. Dla mnie to byla taka lala, nic się nie odzywata, a po chwili poszta $z$ A. do jego pokoju na pietrze. Matka powoda mówita, że pozwana jest taka 
nieśmiała. Nie wiem, czy pozwana gdzieś sie leczyła. Myśmy ostrzegali matke powoda, żeby sie tak nie angażowata, żeby nie przeżyta rozczarowania, że pozwana nie spetni jej oczekiwań. Matka powoda jakby wierzyta, ze pozwana będzie lepszq synowa niż zona starszego syna" (k. 76,4-5). Świadek miał wozić strony do ślubu swoim polonezem, ale pozwana uparła się, że musi to być biały mercedes. O nieporozumieniach poślubnych wie od rodziny powoda. Według świadka ,pozwana wszędzie chodzi ze swojq matka bez niej nigdzie się nie rusza, na weselu m.inn. tańczyla $z$ niq" (k. 77,7). Wbrew wspomnianym wyżej zastrzeżeniem pozwanej nie widać w zeznaniach świadka niczego, co przekreślałoby jego wiarygodność. Świadek wyraźnie różnicuje obserwacje, opinie własne i wiadomości zasłyszane.

Już po publikacji akt świadek nadesłał pismo, w którym z datami opisuje kłótnie między stronami, których był świadkiem. Sprowadzają się one do prowokacyjnego zachowania (,, chodzqc po mieszkaniach (!) wyliczala swoje rzeczy mówiqc do swej matki, że A. w tym wszystkim mieszka" - k. 116). Pozwana te stwierdzenia zdecydowanie kwestionuje, faktem jednak pozostaje, że niektóre szczegóły korespondują z notatką pozwanej, iż $90 \%$ wyglądu domu to jej zasługa (k. 20).

Matka pozwanej, ZD, twierdzi, że powód od początku jej się nie podobal, ,byt jakiś taki dziwny". Zeznaje: "Kiedy chciatam z nim porozmawiać, spuszczal oczy, skladal kolana, skubal się po twarzy". Świadek ostrzegała pozwana, że powód wygląda na nerwowo chorego pozwana go broniła, a świadek nie pojmuje, dlaczego pozwana mając przystojniejszych i bogatszych kandydatów wybrała powoda, świadek nawet pytała męża „co z niq jest, czy ona czasem nie jest oczarowana” (k. $79,5)$. Swiadek nie wie, o co strony - które były razem trzy miesiące kłóciły się, gdyż córka "nie zwierzała się" (k. 80,7). O wydarzeniach, w których uczestniczyła, świadek zeznaje: „U mnie strony tez się któcity, a właściwie pyskowal powód. Nawet mówil mi, żebym zadzwonita do jego rodziców, jeśli chcę. W Nowy Rok zadzwonitam do rodziców powoda. Zapytalam matke powoda, czy wie, że strony się klócq. Odpowiedziala mi, ze sie tego domyśla i od razu zaczęta krzyczeć na mnie, nie dopuścila mnie nawet do glosu. Później spotkaliśmy się na urodzinach córki. Styszałam tylko w przedpokoju krzyki córki i matki powoda. Prawdopodobnie matka powoda powiedziata córce podczas sktadania życzeń, że powinna być poddana powodowi. Awantury żadnej między nami nie byto. Pragnę dodać, 
że przez te 3 miesiace córka praktycznie byta sama. Powód wracal z pracy, jadt obiad i jechat do mamy. Córka byla na zasitku dla bezrobotnych, chciata iść do pracy do sklepu, ale powód jej nie pozwalat. Córka byla mu posluszna. Później 17 stycznia byliśmy na nieszporach kolędowych, między stronami byto jeszcze wszystko dobrze. Po kilku dniach córka przyszla do nas. Powiedziala, że strony się poklócily poprzedniego dnia i powód wrócil o godz. 1.30 w nocy. Córka zostawila mu kartke, że odchodzi. Postanowila jednak wrócić. Odwieźliśmy jq chcieliśmy porozmawiać z powodem. Zadzwoniliśmy do jego rodziców. Powód jednak nie przyjeżdżat. Mąz $z$ synem pojechali tam. W międzyczasie przyszedt powód. Wygladal dziwnie, krzyczal po córce, co tu robi, ze ma sie wynosić z jego mieszkania. W tym czasie wrócit maż. Tam byla jakaś szamotanina. Raz syn uderzyt w twarz powoda, poniewaz zachowywal sie histerycznie, wybiegt na balkon, jakby chcial wyskoczyć. Pod blokiem byt ukryty ojciec powoda $i$ za chwile przyjechat z milicja. Strony póziniej byly jeszcze razem do 16 kwietnia. $W$ międzyczasie córka raz jeszcze odeszla. Miata nerwice serca. Prosila powoda, by zostat z niq, ale on pojechal na narty. Powiedzial, że nie bedzie sobie przez niq marnowat życia. Córka zaszla jeszcze $w$ ciaże, choć podobno powód wcześniej nie chciat mieć dzieci. Powód jeździt sam do swoich rodziców, choć córka chętnie by z nim jechata" $(\mathrm{k} .80,7)$.

Brat pozwanej, TD, twierdzi, że jest ona osobą samodzielna, zaś zdanie, jakoby była uzależniona od własnej matki, uważa za bzdurę $(\mathrm{k} .81,5)$. Miesiąc po ślubie widział pozwana, „ze tzami w oczach”, jednak nie chciala nic mówić. "Pierwszy raz odeszla od powoda, bo z nim nie dato się wytrzymać”, świadek przypuszcza, że „z powodem nie da sie żyć (k. $81,7)$.

Zeznawała również $\mathrm{KW}$, która „prowadzi pozwanq od 16 roku życia jako ginekolog". Wedle zapisu świadek przepisywała pozwanej lekkie środki uspakajające, w trakcie ciąży nasiliły się u niej stany nerwicowe. Kiedy wreszcie strony zjawiły się u świadka razem, pozwana „wywolała zeznaje świadek - bardzo glosina scysję. Nie dopuszczala nikogo do gtosu. Wykrzykiwala tylko różne zarzuty pod adresem powoda. Powód chcial pewne sprawy tlumaczyć, ale ani on, ani ja nie zostaliśmy dopuszczeni do głosu. Po tej wizycie doszlam do wniosku, czy nie powinno się skierować pozwanej do psychiatry. Uważalam, że może to być bardzo ciężka nerwica. Pozwana jednak więcej się nie pokazala u mnie. Później jeszcze dzwonit powód, czy pozwana przyszla do mnie. Żalit sie, że nie może nawiqzać $z$ 
pozwanq kontaktu. Pragnę dodać, że pozwana zarzucila mi, że biorę stronę powoda, co nie jest prawda. On zrobit na mnie wrażenie człowieka sklonnego do ugody. Natomiast zachowanie pozwanej mnie przerażato. Powód skarżyl się, że pozwana nie chce nic dźwigać, ugotować mu obiadu, bo jest w ciaży. Pytal mnie, czy ona rzeczywiście nie może nic dźwigać. Wygladalo na to, że ciaża byla dla pozwanej pepkiem świata, że pozwana wyszła za maż tylko po to, by mieć dziecko. Pragnę dodać, że każda ze stron inaczej przedstawiala swoje sprawy. To co strony mówily, byto sprzeczne, np. powód twierdzil, że chciat podwieźć pozwana, ona zaś, że ja zostawil. Powód twierdzi, że pozwana nie chce mu pokazać dziecka, matka pozwanej zaś mówila, że on sie nie interesuje dzieckiem. W marcu pozwana byla u mnie z pretensjami, że bronię powoda" (k. 81-82,3).

Zaznajomione $\mathrm{z}$ zeznaniami strony zdecydowanie polemizuja $\mathrm{z}$ zeznaniami świadków strony przeciwnej. Jednak - podobnie jak świadkowie - zapuszczają się w szczegóły nieistotne dla sprawy (np. czy pozwana dyrygowała gośćmi weselnymi względnie czy powód chciał wyjechać $\mathrm{w}$ góry z pozwana). Obydwie strony podważają też zeznania $\mathrm{dr}$ KW: pozwana przeczy, by przepisywano jej środki uspokajające, powód nie zgadza się ,, z diagnozq jego charakteru” (powód chyba źle odczytał zeznania świadka twierdząc, że p. KW przypisuje mu brak dobrej woli - $\mathrm{k}$. 110 , świadek zeznała akurat odwrotnie - k. 81,3). Strony wzmacniają swe wywody kopiami zaświadczeń czy pism, w większości niestety odległych od przedmiotu sprawy. Zeznanie lekarki, że od r. 1980 przepisywała jej środki uspokajające, pozwana zwalcza zaświadczeniem pani dr FZ, iż wedle kserokopii kart chorobowych od r. 1980 - też zresztą załączonych do akt (k. 95-97) - pozwana nie brała środków uspokajających, z wyjątkiem okresu ciąży od kwietnia 1991 (k. 94). Jednak pod datą 24.7.1980 widnieje zapis „nerwowa” (k. 95). Pozwana nie ogranicza się do repliki, lecz występuje z nowymi zarzutami, których podbudowaniu mają służyć załączniki. I tak pozwana na potwierdzenie swego zdania, iż powód oraz jego ojciec są zboczeni i , chyba sypiajq razem" przedłożyła zaświadczenie o czasowym zameldowaniu ojca powoda w mieszkaniu powoda. Niezależnie od logiki tej argumentacji i pewności, z jaką stawia się zarzuty (,sq zboczeni" - k. 90) zalaczony dokument (rubryki pytania i odpowiedzi wypełniła ta sama osoba!) jest zbędny, gdyż ojciec powoda zeznając w Sądzie taki właśnie podał adres (a fakt zameldowania tłumaczy później powód umożliwieniem ojcu doglądania mieszkania pod jego nieobecność - 
k. 155). Pozwana nie szczędzi zresztą mocnych określeń: „czysty wymyst”, „,czysta paranoja”, ,.czyste klamstwo", „,ksiadz pisat bzdury”, , bezczelnie kłamie”, , cechuje ich bylejakośc i niechlujstwo".

Powód jest w polemice nie mniej drobiazgowy, pozostaje jednak daleki od zwrotów, jakimi posługuje się pozwana. Co więcej, potrafi krytycznie ocenić niektóre swoje kroki i przyznać się do błędów (np. w sprawie wymiany zamka - k. 106).

Akta sprawy przedłożono 28.4.1992 biegłej psycholog, dr SM. Biegła diagnozuje na podstawie akt niską zdolność stron do "wczuwania się w świat myśli i przeżyć partnera", postawy egocentryczne u obojga, niską ich odporność na sytuacje trudne i niepowodzenia, "pewien infantylizm" i „zbytnia koncentracje na zadaniach prokreacyjnych" u pozwanej, „pewne rysy psychopatyczne" w zachowaniach powoda, uleganie przez obydwie strony wyraźnym wpływom rodzin macierzystych. Wedle biegłej obydwie strony to ,osobowości nie $w$ pelni dojrzate do samodzielnego, konstruktywnego i satysfakcjonujqcego oboje wspólzycia w malżenstwie", co jednak ,, nie oznacza, iż strony w ogóle nie byly zdolne podjać $i$ wypetnić podstawowych obowiazków matzeńskich". Zdaniem biegłej "powód $i$ pozwana $w$ dniu zawierania matzeństwa posiadali nie $w$ petni prawidlowo uksztaltowane osobowości, które utrudniaty stworzenie harmonijnie funkcjonujacej wspólnoty malżeńskiej, nie znosity jednak $w$ ogóle ich zdolności do podjęcia i wypelnienia istotnych obowiqzków małżenskich " (k. 84-87).

Sąd uwzględnił wniosek powoda ,o wlączenie do akt sprawy wyników badan'" przeprowadzonych przez dra HK, gdy strony konsultowaly go w Diecezjalnej Poradni Życia Rodzinnego. Jego opinia brzmi następująco: „Badana charakteryzuje się bardzo duża dyssymulacja, czyli ukazywaniem siebie w o wiele lepszym świetle, aniżeli to jest w rzeczywistości. Mimo tej duzej dyssymulacji - zafatszowanie wyników w kierunku bycia „lepszq" test wykazal podwyzszony wynik $w$ skali paranoi. Wywiad potwierdzit istnienie u badanej silnej podejrzliwości, sztywności myślenia. Uderza w niej niezwykle barwny opis tego, jak to jest prześladowana przez męża, co ma charakter już urojeniowy. Z wywiadu wynika, ze motywem zawarcia malżenstwa byl strach: maż jakby szantażowal ja samobójstwem. Uzupetnieniem do postawionej tutaj diagnozy może być zachowanie się tej pani wraz z matkq która zdradza bardzo podobne cechy co córka - owa wlaśnie pani. Czy nie mamy więc tutaj do czynienia z pewnymi cechami 
dziedzicznymi? Paranoja należy bowiem do zaburzeń o charakterze endogennym. Jeśli chodzi o męża tej pani, test WISKAD wykazat jedynie pewne odchylenia od normy w skali MK - seksualnej. Wywiad potwierdzit, że u pana wystęuje skrzywienie pracia. Reasumujac - wysuwam hipoteze o niezdolności badanej do zawarcia trwatego zwiqzku matżeńskiego, opartego na umiejętności zrozumienia partnera" (k. 145).

W takim stanie sprawy Sąd ponownie przedłożył akta sprawy - łącznie z opinią dra HK. - p. dr SM. Biegła skorygowała swoją opinię, przyjmujac jako przesłanki (1) zeznania dr KW, (2) informacje świadka EJ, (3) wyniki badań dra HK. Biegłej "trudno zakwalifikować osobowość pozwanej do jakiejś jednej kategorii nieprawidlowej osobowości”. Biegła pisze: ,Obok bowiem cech tzw. paranoidalnych (podejrzliwość, sztywność myślenia, urojenia prześladowcze) charakterystyczny dla jej osobowości jest infantylizm, ujawniajacy się $w$ dominacji postawy egocentrycznej, w stabo rozwiniętej uczuciowośsi wyższej, w braku empatii, w wyraźnej zależności emocjonalnej od matki. Cechy powyższe występowaly $w$ osobowości pozwanej juz $w$ akresie przedmalieńskim $i$ czynity jq niezdolnq do samodzielnego i odpowiedzialnego petnienia roli malżeńskiej" (k. 150). Stąd konkluzja biegłej: „Reasumujqc, orzeka się, że pozwana GD w dniu ślubu nie byla zdolna podjać $i$ wypetnić istotnych obowiqzków matzeńskich ze względu na nieprawidlowa osobowość, tj. osobowość o cechach infantylnych oraz paranoidalnych" (k. 150). Tę opinię biegła potwierdziła zeznając wobec Sądu (k. 151).

Opinia dra HK. i zmieniona opinia dr SM wywołała lawinę listów pozwanej i jej rodziny. Brata pozwanej ,mdli czytajac zeznania A. jak również jego matki" (k. 161). Ponieważ akta czytały wyłącznie strony, trzeba przyjąć, że materiał dowodowy został udostępniony osobom trzecim przez pozwaną. O wartości tych listów świadczą takie zwroty jak ,,(biegły) rozbija i pomaga unieważnić święty sakrament - matżeństwo wymyślajac bajki o mojej siostrze i matce” (k. 160) lub ,,ludzie pracujacy w instytucji kościelnej pomagaja psychopacie robić z normalnego zdrowego czlowieka wariata" - (TD, k. 166). Nie brakło też ,kategorycznego domagania się" wyjaśnień, m.inn. uprawnień dra HK (JD, k. 199) i dr SM (TD, k. 166). Podobnych żądań było więcej (ZD, k. 220, JD, k. 243), nie brakło też zarzutów takich jak ten, że ", biegly pisze bzdury pod dyktando zięcia" (ZD, k. 220). Pomijając już fakt, że poza stronami nikt nie ma praw interwencji $w$ procesie, trzeba stwierdzić, że pozwana godząc się na te listy 
jakby straciła z oczu przedmiot procesu. Sąd nie mógł odpowiadać na takie skierowane doń żądania, musi natomiast zaliczyć otrzymana korespondencję do materiału dowodowego. Nie pozostaje ona bez znaczenia dla oceny wiarogodności ich autorów (np. TD ,zaprzysięga” swe twierdzenie o „manipulacjach psychopaty" (k. 166). Co więcej, pisma te prowadza do wniosków wprost przeciwnych zamierzeniom ich autorów. Np. wielokrotnie zwalcza się w nich „silny zwiqzek” pozwanej z matką (, kwestia silnego zwiqzku siostry z mojq matka jest kompletna bzdurq, gdyz taki zwiqzek nie istnieje" - TD, k. 162), a przecież przeczy temu czynne zaangażowanie rodziny pozwanej w proces, przy czym listy pozwanej, jej ojca, matki i brata pisane są tym samym stylem, posługują się identycznym słownictwem, świadczą o jednakowym sposobie myślenia, przede wszystkim zaś dowodza, że rodzina pozwanej traktuje sprawę o orzeczenie nieważności jej małżeństwa jako swoją (TD - zaprzysięgając - ,zapamięta na zawsze" nazwisko $\mathrm{HK}-\mathrm{k}$. 165) i to calkowicie według pojmowania sprawy przez pozwaną. Wbrew intencjom autorów, ich gotowość zaprzysiężenia (np. k. 166, 168) takich i tak sformułowanych zarzutów, a w odniesieniu do dra HK po prostu brutalnych pomówień, każe Sądowi zwrócić uwagę na stwierdzenie matki powoda: "G. $i$ jej rodzice często chcieli przysiegać na Krzyz i Biblie, mimo ze klamstwa byly ewidentne, a przysiegi nikt nie wymagal" (k. 115). Sąd z przykrością kojarzy te wypowiedzi, nie mniej jednak znajdują się one w aktach sprawy.

W zaistniałej sytuacji Sąd musiał zasięgnąc kolejnego biegłego. Mgr WS sporządził ja opierając się na aktach sprawy $\mathrm{i}$ badaniu przeprowadzonym w siedzibie Sądu (ale nie dokończonym $\mathrm{z}$ powodu odmowy pozwanej dokończenia testów psychologicznych). Biegły ocenia dość wysoko wartość diagnostyczną akt, a to ,ze względu na możliwość rozróżnienia dwóch warstw w pisemnych wytworach stron: faktycznej (opisujacej subiektywnie spostrzegane wydarzenia) $i$ formalnej interpretacyjnej (odnoszacej się do sposobu formulowania wypowiedzi, ich cech psychologicznych oraz do sfery interpretacji dotyczacych zachowań strony przeciwnej)" (k. 210). Odpowiedź biegłego na pytania Sądu brzmi: „Analiza materialu zgromadzonego w aktach sprawy oraz uzyskanego badaniem psychologicznym wskazuje na istnienie po stronie pozwanej cech psychicznych uniezdalniajacych do prawidlowego funkcjonowania $w$ tym zwiqzku malzeńskim. Przyczyny te omówiono w części dotyczqcej wyników badań psychologicznych, a krótko rzecz ujmujac: zawieraja się $w$ 
niedojrzalości uczuciowej i nadmiernie intensywnym zwiqzku z matka - co uniemożliwia powstanie uczuciowej więi pomiędzy stronami jako podstawy autonomicznej wspólnoty malzeńskiej. Badanie nie wskazuje na podobnq sytuacje po stronie powoda. Trudno jest orzec, czy niezdolność do podjęcia obowiazków malżeńskich jest absolutna. Należy dopuścić możliwość (przynajmniej teoretyczna) rozwoju emocjonalnego badanej i jej autonomii uczuciowej. Jednakże biorac pod uwage historie zwiazku stron z dużym prawdopodobieństwem można stwierdzić, iż nie należy oczekiwać możliwości powstania wspólnoty matżeńskiej w przypadku tego zwiqzku. Należy przyjąć, iż stan uniemożliwiający podjęcie najistotniejszych obowiqzków malżeńskich istnial $w$ chwili zawierania malżeństwa. Historia zwiqzku oraz wyniki badania wskazuja na brak możliwości wyrównania istotnych deficytów - przeciwnie, okres ten ujawnil je oraz byt czasem narastania intensywności ich (deficytów) konsekwencji" (k. 213-214).

Pozwana również tę opinię zwalcza zdecydowanie, twierdzi, iż opiera się na insynuacjach, zaś jej opinia sprowadza się do następującej: „Jak widać pan psycholog splycit i uogólnit sprawę w sposób w petni korzystny dla męża, a stanowisko psychologa $w$ tej kwestii należy uznać za zastanawiajace, gdyż nie pokrywa się z prawda, faktami $i$ siwiadkami, których posiadam na te okoliczności" (k. 229). Nie brak w pismach pozwanej takich określeń opinii biegłych jak ,kompletna bzdura" (k. 237) - i wielokrotnie - „brednie” (k. 233). Co więcej, pozwana nie waha sie twierdzić, iż psycholog sądowy pisał, jak sobie tego życzył powód (k. 232).

Pozwana powołuje się na opinię osób - jej zdaniem - bardziej kompetentnych niż te, do których zwrócił się Sąd. Przedłożyła cztery zaświadczenia:

1. Psychologa dra ZM z 22.6.1991, który ,na podstawie trzykrotnych rozmów $i$ badań psychologicznych w okresie od lutego do czerwca 1991" stwierdza: "nie ujawnilem objawów świadczqcych o zaburzeniach psychotycznych, zaburzeniach osobowości i poziomu intelektualnego. $W$ chwili obecnej u pacjentki występuja silne objawy nerwicowe o charakterze reaktywnym sytuacyjnym wywolane sytuacja matżeńskq. Za wskazane uważam oddziatywania psychoterapeutyczne" (k. 39).

2. Psycholog mgr JT, która badała pozwaną 21.6.1991 i nie stwierdziła zaburzeń psychicznych ani odchyleń od normy w myśleniu i zachowaniu (k. 40). 
3. Psycholog mgr KS wydał 5.11.1993 zaświadczenie, że nie stwierdził u pozwanej „zaburzeń typu nerwicowego i psychicznego oraz zaburzeń osobowości". Psycholog zaznaczył, że „w/w ob. jest osoba dojrzata emocjonalnie" (k. 234).

4. Neurolog-psychiatra KF wydał dnia (data nieczytelna) zaświadczenie wprawdzie nieczytelne, ale można domyślać się, iż zaświadcza, że nie stwierdził objawów nerwicy ani psychotycznych (k. 235).

Dwa ostatnie zaświadczenia miały być repliką na opinie biegłych Sądu. Do autorów dwóch pierwszych Sąd zwrócił się z odpowiednimi pytaniami, JT nie odpowiedziała w ogóle, pismo do dra ZM, skierowane do podanej na jego pieczątce skrytki pocztowej, wróciło $\mathrm{z}$ adnotacją , nie podjęto $\mathrm{w}$ terminie" (k. 202). Pozwana twierdzi, że JT nie otrzymała tego listu (k. 233). Z kolei powód zwalcza dwie pierwsze opinie twierdząc, iż podczas rozprawy rozwodowej dr ZM zeznał, że wydał zaświadczenie , po wielokrotnych prośbach i naleganiach" pozwanej (k. 138). Niezależnie od tego Sąd nie może nie zwrócić uwagi na formę tych zaświadczeń, które oczywiście - podlegają ocenie Sądu, przeprowadzonej w świetle całokształtu materialu dowodowego.

W materiale dowodowym najwięcej miejsca zajmuja pisma stron. Obydwie strony zapuszczają się w drobiazgowe analizy różnych epizodów, które wprawdzie były ważne $w$ ich pożyciu, ale nie stanowią przedmiotu sporu. Pytanie procesowe nie dotyczy bowiem winy za rozpad małżeństwa, lecz zdolności stron do nawiązania takiej wzajemnej relacji międzyosobowej, jaką jest nierozerwalne małżeństwo. I tu nasuwa się jeden, nieodparty wniosek: w tym związku ,wszystko", tzn. rzeczy wydawałoby się bardzo drobne, stawało się problemem. W aktach sprawy latwo znaleźć tego potwierdzenie - jak np. - wspomniane już wyżej wskazanie zameldowania ojca powoda (k. 93) czy też dowód nadania listu do powoda na adres jego matki (k. 98). Takie szczegóły absorbują pozwaną nieproporcjonalnie do ich wagi. Co więcej, skłaniają pozwaną do uogólnień i do wysuwania zarzutów, co do których powinna przecież była zdawać sobie sprawę, iż będą przez Sąd weryfikowane i oceniane. Pozwana ma prawo nie zgadzać się z opiniami biegłych, ale treścią i formą polemiki wystawia świadectwo sobie, nie biegłym. Nie bez znaczenia dla oceny materiału dowodowego pozostają takie twierdzenia, jak to, że HK wysuwa insynuacje (np. k. 230) i ", nie wie, o kogo chodzi i o kim pisze" (k. 248), że w Sądzie Biskupim „psycholodzy tworzq nowe bzdurne hipotezy i teorie" 
(k. 230 i 249), że „istnieja uprzedzenia" co do jej osoby (k. 230), że zmiana opinii biegłej to hańba (k. 249), że ,stala się ofiarq" pomyłki i fałszu (k. 250). Właśnie to, iż pozwana uważa się za ofiarę, jest symptomatyczne. Nie chodzi tylko o dokonaną ocenę (,pomyłka", ,falsz"), lecz o pogląd, jakoby w procesie o orzeczenie nieważności ktokolwiek miał być ofiara czy - jak pisze pozwana - ona , miata ponieść ofiare niudanego malżeństwa" (k. 250), o którego orzeczenie nieważności sama wnosi (k. 236 i 248), tyle że nie z jej ,, strony" (k. 248).

Akta sprawy, w szczególności zaś pisma pozwanej, potwierdzają zdanie $\mathrm{HK}$, iż kto jest innego niż pozwana zdania, zostaje przez nią oceniony jako wróg, któremu nie skapi się najbardziej dosadnych określeń. Za wrogów uznaje powoda, jego rodzinę, innych świadków zeznających wedle oceny pozwanej niekorzystnie (EJ, KW), biegłych, wreszcie Sąd czy wręcz Kościót, jak to wynika z ostatniego akapitu jej głosu obrończego (k. 250). Wobec takiego stanowiska Sąd pozostaje bezradny, jednak nie może ulegać groźbom (,nie powinnam dalej być katoliczka" -. k. 250), lecz musi odpowiedzieć na pytanie procesowe zgodnie z obiektywnym materiałem dowodowym. Sąd nie może spełniać życzeń jednej ze stron (np. uznać za miarodajne $\mathrm{i}$ wiarygodne te opinie, które pozwana za takie uznaje $-\mathrm{k} .172$ ), lecz ma orzekać o prawdzie.

Prawda, o jaką chodzi, to pytanie, czy małżeństwo zostało zawarte nieważnie $\mathrm{i}$ to $\mathrm{z}$ powodu niezdolności do podjęcia $\mathrm{i}$ wypełnienia istotnych obowiązków małżeńskich po stronie powoda lub/oraz pozwanej.

Sąd nie znajduje wystarczających podstaw do odpowiedzi pozytywnej odnośnie do powoda. Nie uznają go za niezdolnego do małżenstwa biegli, nie wynika taka niezdolność z materiału nagromadzonego w aktach sprawy. W szczególności trzeba stwierdzić, iż wyciągnięcie wniosku o niezdolności powoda utrudniaja pisma pozwanej i jej rodziny, zawierają bowiem - także - zarzuty ewidentnie fałszywe, a w odniesieniu do biegłych Sądu nieprzebierające $w$ słowach. Dodać trzeba, że ten tytuł nieważności Sąd przyjął na podstawie pism pozwanej, urażonej skarga powoda i odwracającej tytuł nieważności wniesiony przez niego. Dyspozycja kan. 1095 n. 3 nie może być w tym przypadku zastosowana.

Odnośnie do pozwanej przytoczone wyżej opinie dr. SM (zmodyfikowana) oraz mgr WS zawierają konkluzję odmienną. Nie da się ukryé, że opinia biegłych znajduje potwierdzenie w materiale dowodowym, przy czym niemałe znaczenie ma dla Sądu sposób zwalczania przez 
pozwaną opinii uznanych przez nią za niekorzystne dla siebie. Akta sprawy, oceniane zgodnie z kanonicznymi regułami dowodzenia, prowadzą Sąd do wniosku, iz pozwana - z racji, o których wyżej - nie była $\mathrm{w}$ dniu 20.10.1990 zdolna do nawiązania takiej relacji międzyosobowej, jaka jest małżeństwo. Tym samym spełniają się wymogi kan. 1095 n. 3.

Wobec takiego stanu sprawy Sąd Metropolitalny - mając Boga przed oczyma - orzeka, iż u d o w o d n i o n o nieważność małżeństwa. 